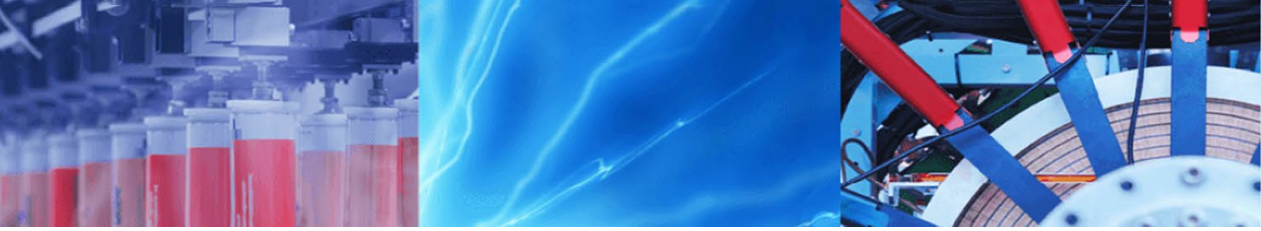

Research Article

\title{
PIV measurement and CFD simulations of an air terminal device with a dynamically adapting geometry
}

\author{
Nina Szczepanik-Scislo ${ }^{1}$ (D) Arkadiusz Antonowicz ${ }^{2} \cdot$ Lukasz Scislo $^{3}$ (D)
}

C The Author(s) 2019 OPEN

\begin{abstract}
Air quality is an important factor for human well-being, and it is crucial that when using mechanical ventilation system, air is properly distributed so it reaches every user of a ventilated zone. To improve ventilation systems, and in consequence the air quality, this paper focuses on studying the impact of an air terminal device (ATD) with a dynamically changing geometry on the effectiveness of a variable air volume (VAV) ventilation system. VAV system characterizes a change in the airflow magnitude through the system when the heat gains lower, which may be a risk for human health as air may not reach the furthest parts of a zone. To combat this threat, an ATD with a dynamically changing geometry was installed. As a ventilation quality indicator, the air throw was taken under consideration. Thanks to the new ATD, the steady air throw should be maintained despite the changes in flow in the ventilation system. To achieve this, the research was divided into two stages. The first stage included a series of computational fluid dynamics simulations that considered the alteration of the airflow and the air terminal device diameter. Afterwards, verifying laboratory measurements were conducted on a laboratory stand using a particle image velocimetry (PIV) system that included an air terminal device with a changing geometry. The results of the simulations and the PIV measurements showed that the changes in the geometry of the air terminal device improve the ventilation effectiveness of a VAV system, allowing the system to maintain a constant air throw despite the changing airflow magnitude through the system.
\end{abstract}

Keywords VAV ventilation systems · PIV measurements · Particle image velocimetry · Indoor air quality

\section{Introduction}

The problem of maintaining proper indoor air quality (IAQ) is an ongoing subject and a topic of many research papers [1-5]. The topic is extremely important in developed countries where there is a trend to tighten the building envelope for energy savings by lessening the heat losses to the outdoor air. This trend has also been fuelled by new laws. According to European regulations by 31 December 2020, all new buildings should be nearly zero-energy buildings and after 31 December 2018, new buildings occupied and owned by public authorities should be nearly zeroenergy buildings. To limit the energy losses, such objects are usually extremely airtight, to prevent uncontrolled air leakages through the building envelope.

Because many current ventilation systems may not maintain adequate thermal and hygienic comfort nor adapt to the growing airtightness of buildings, ventilation systems should be improved to keep up with new construction methods that enforce the creation of increasingly tight structures, as emphasis is mainly put on energy savings and the air quality may be omitted. Therefore, the work in this paper focused on improving air quality in VAV (variable air volume) systems, which are used in large buildings and which usage is increasing in small energyefficient residential buildings.

\footnotetext{
$\triangle$ Lukasz Scislo, lukaszscislo@gmail.com | ${ }^{1}$ Faculty of Environmental Engineering, Tadeusz Kosciuszko Cracow University of Technology, 24 Warszawska Str., 31-155 Kraków, Poland. ${ }^{2}$ Eurotek International Ltd., 6 Skrzetuskiego Str., 02-726 Warsaw, Poland. ${ }^{3}$ Faculty of Electrical and Computer Engineering, Tadeusz Kosciuszko Cracow University of Technology, 24 Warszawska Str., 31-155 Kraków, Poland.
} 
VAV systems supply a variable volume of air at given, stable parameters to a room, depending on the current needs. The airflow changes when the heat load in the room changes, so that the objects do not overheat or cool too rapidly. The advantage of this type of systems is the energy savings associated with the operation of the fans as well as the smaller heat fluxes that may be provided by the chillers and/or heat sources in the ventilation unit. Also, there is a possibility of engine room equipment reduction. This is possible thanks to the lowering of heat loads within the building.

However, when considering airtight buildings, there is a concern that such systems may not provide sufficient fresh air to the entire volume of large spaces such as sports halls, swimming pools or open-space work areas. The reason for this is that with the reduced heat gains (e.g. during a cloudy day), less air enters the room. Air from the terminal device does not have the same range of flow as system with the maximum capacity airflow and may not reach all the occupants. This may result in deterioration of air quality which directly affects the physical and mental condition of the occupants [6]. Lack of proper air quality may cause a drastic drop in the concentration, productivity and vigilance of employees [7, 8].

To improve the effectiveness of VAV systems, the presented work focuses on the final element of the ventilation system, i.e. on the air terminal device (ATD). According to many studies, the position and shape of the air terminal device have proved to be crucial for the airflow in a room $[9,10]$. The work is intended to investigate by means of computer simulations and test conducted using the particle image velocimetry (PIV) method to evaluate whether the use of an air terminal device with a dynamically changing geometry will improve the air quality in a large ventilated zone.

As an indicator of the quality of the air terminal device operation, the air throw of the air terminal was selected. The proper range of the stream indicates the area in which fresh air reaches the room. If the air throw of the jet falls with the flow of air magnitude through the VAV system, the system will not deliver the appropriate amount of fresh air to the distant areas of the room. Maintaining a steady air throw would also reduce the size of the installation and would be beneficial in large areas where an extensive fresh air supply system is required.

\section{Experimental procedures}

The aim of the study was to determine whether it was possible to maintain a constant air throw when the airflow magnitude changed. To achieve this, the focus of the study was divided into two parts. First, a series of computational fluid dynamics (CFD) simulations were carried out to define the optimal parameters for the air terminal device. This allowed the validation of different options and the selection of the most optimal one. Afterwards, PIV measurements took place using the test air terminal device in two different control distances to observe how the air throw changed and corroborate whether the simulation results correlated with the measurements. The experimental study was carried out on an air terminal device that was connected to a fan with an inverter that allowed the alteration of the flow within the system to reflect the conditions within a VAV system. The laboratory stand (Fig. 1) was built according to European norms [11]. The air terminal device on the laboratory stand had a changing geometry that was altered depending on the airflow. The aim was to maintain the air throw at a stable distance. In the study, the air throw was assumed as the distance from the air terminal device after which the air velocity would fall below $0.5 \mathrm{~m} / \mathrm{s}$. After de-acceleration to such velocity, it would no longer reach further parts of the ventilated zone.

The diameter of the air terminal device could be changed according to the signals in the VAV system. With the lowering of the airflow, the diameter was automatically changed to accelerate the fresh air and maintain the necessary air throw. A detailed description of the air terminal device can be found in [12]. Two settings of the ATD were used in this study:

- ATD setting 1 -effective diameter DATDef $=200 \mathrm{~mm}$; effective ATD area: AATDef $=30961 \mathrm{~mm}^{2}$;

- ATD setting 2-effective diameter DATDef $=100 \mathrm{~mm}$; effective ATD area: AATDef $=7631 \mathrm{~mm}^{2}$.

\subsection{Experimental set-up}

There are a number of methods available for measuring jet velocity vector field for ventilation systems, each with its own advantages and disadvantages. However, the PIV method has become a more popular way to measure airflows and their characteristics in the past years due to its

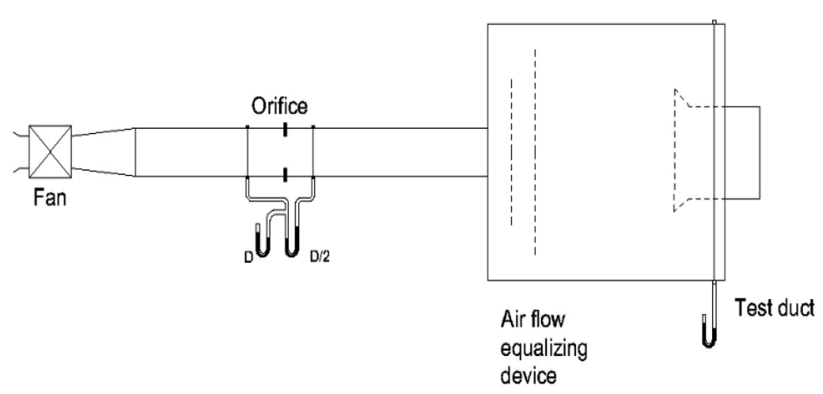

Fig. 1 Laboratory stand layout according to PN-EN 12238:2002 
nonintrusive measurement method. In addition, PIV has advantages of measuring the velocity field for each instant in a given time frame [13-15]. Thanks to these features, it is possible to measure the characteristics of airflow very accurately. This is why a 2D-PIV system was chosen as the method to define airflow changes in a VAV ventilation system with a dynamically changing geometry of the air terminal device to determine how air throw changed with the changing air magnitude and air terminal device diameter.

\subsubsection{D-PIV measurement}

The PIV measuring system is based on dispatching tracer particles in a flow stream that are later illuminated by a laser. The laser sends out signals at a given time interval and reflects light off the tracer particles. The reflection is monitored by a camera. Thanks to the known time frame of the laser measurements, it is possible to calculate the velocity of the flow stream.

The 2D-PIV measurement system is shown in Fig. 2 and was carried out using a laser tracing system. In this study, a two-pulse laser (Evergreen EVG 200-15, 2×200 mJ at $15 \mathrm{~Hz}$ ) was used to detect the airflow from the air terminal device. An optical arm and light knife forming optics as well as PIV HiSense Zyla 5.5Mpix camera $(2560 \times 2160$ pix) were used to take pictures of the flow. A seeding generator with SMD-generated particles $(2-5 \mu \mathrm{m})$ was used to generate the marker for the air, its role was to reflect the light of the laser and in consequence allow the flow measurement. The used particles had a good following and adhesiveness, and the response time to the motion of the air is reasonably short to accurately follow the flow. In addition, a 532-nm FWHM $10 \mathrm{~nm}$ optical band filter was used. The equipment was connected to a desktop computer which used the software Dynamic Studio v5.1 for measurements analysis. The set-up allowed the accurate measurement of the airflow.

Measurements were taken at a $15 \mathrm{~Hz}$ interval between pulses in generated pairs, adjustable with flow velocity and measuring surface in the range of 200-1000 $\mu$ s. During the studies, the $336 \times 284 \mathrm{~mm}$ sections were taken under consideration by the PIV technology.

\subsubsection{CFD simulation set-up}

For the CFD (computational fluid dynamics) simulations, the software ANSYS Fluent was used. It was chosen as it allows the modelling of complex flow-related phenomena (turbulence, multiphase flows, chemical reactions, heat transfer, radiation, etc.) [16]. It has been used in many complex applications that include airflows, complex geometries and air terminal devices [17-20], thus proving to be a valid tool and the reasonable choice for this study.

Fig. 2 PIV measurement set-up

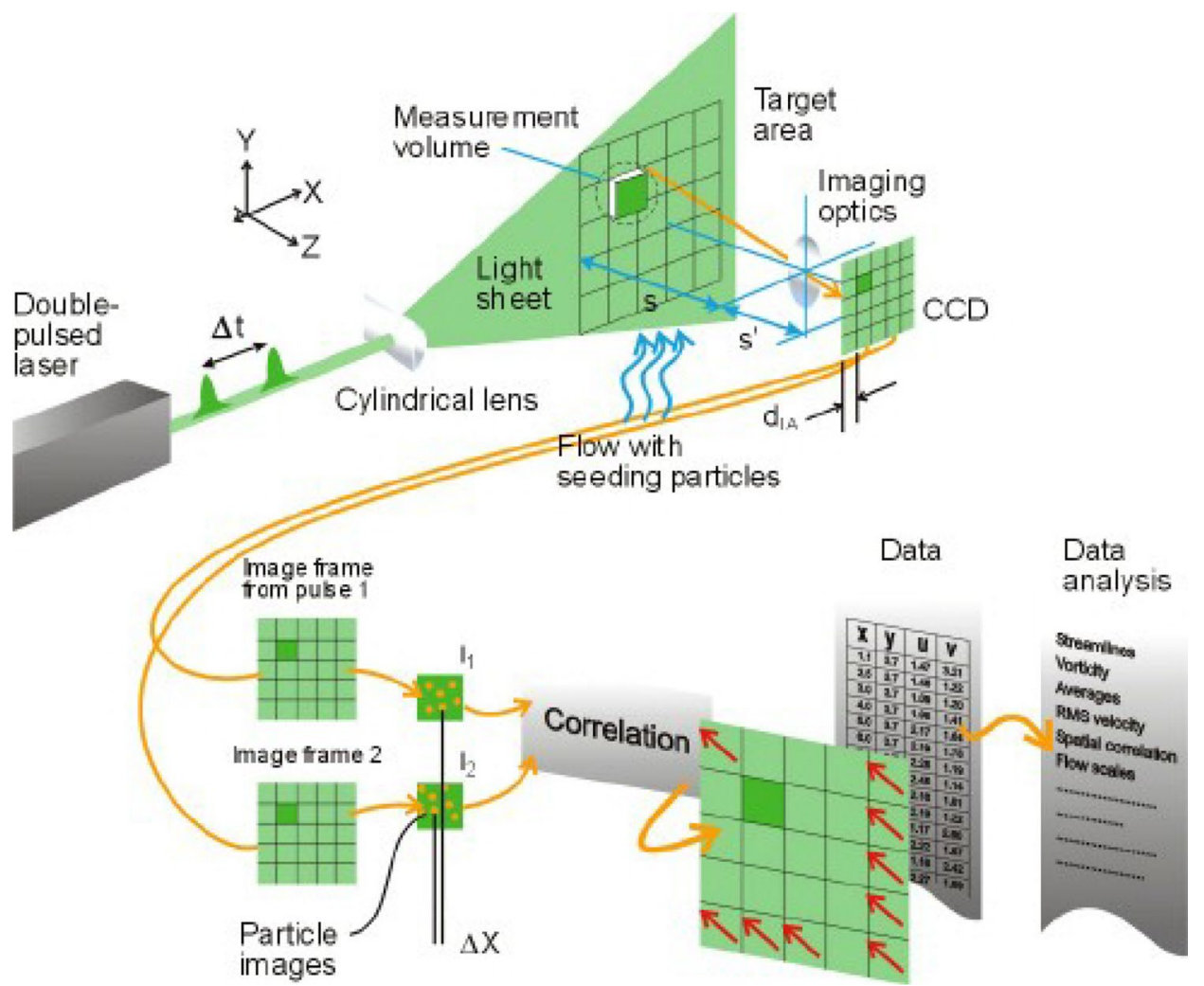

SN Applied Sciences 
During the simulation, a turbulent model $k-\varepsilon$ was used: a model of two equations in which the turbulent viscosity depends on kinetic energy " $k$ " and turbulent dispersion " $\varepsilon$ " [21]. Additionally, the program has already been used to study strictly air terminal devices [22, 23], and the impact of ventilation and air-conditioning systems on air quality and thermal comfort for many years $[24,25]$.

The geometry model is presented as an axisymmetric one and is shown in Fig. 3. This model assumes that the presented geometry is rotated around a given axis and thus transforms the 2D model into 3D model. This model was chosen because the considered geometry is symmetrical, and it allows the reduction of the number of nodes in the model, which speeds up the calculation process and allows for a more detailed mesh.

Like the PIV measurements, the geometry of the air terminal device as well as the airflow was altered accordingly throughout the simulations.

\section{Results}

Results from the PIV measurement system and CFD simulations were compared and contrasted. It was decided that the measurements would take place in two different control distances along the airflow from the air terminal device:

- At the length of $0 \mathrm{~m}$ from the air terminal device.

- At the length of $6 \mathrm{~m}$ from the air terminal device.

Both cases were carried out for two extreme flows through the system - the maximal airflow $(0.25 \mathrm{~kg} / \mathrm{s})$ and minimal airflow $(0.12 \mathrm{~kg} / \mathrm{s})$. This was done to observe how the air velocity changed throughout the systemand in consequence how the airflow range changed when the air magnitude was altered. The diameter of the air terminal device was changed in the measurements as well as the simulations to assess whether this alteration

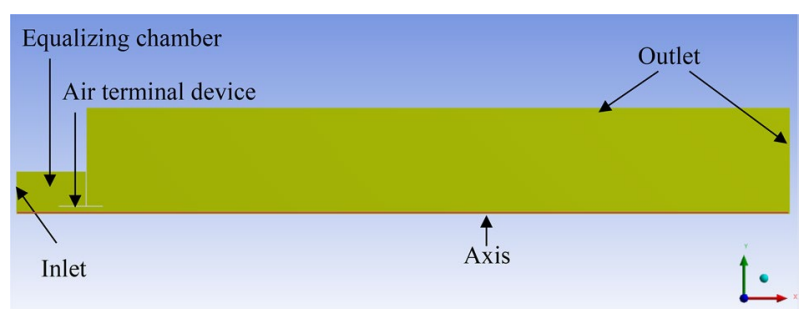

Fig. 3 Geometry of the ANSYS fluent model positively influenced the air velocity and in consequence the air throw.

\subsection{Measurement distance from the air terminal device: $\mathbf{0} \mathbf{m}$}

For the first case, the distance from the air terminal device was $0 \mathrm{~m}$. First, the maximum flow was activated with the ATD setting 1 to observe how the airflow formation occurred. Afterwards, the air magnitude was lowered to the minimal flow. To adapt to the changes in the air velocity, the diameter of the air terminal device was altered to a minimum to improve the air throw and accelerate the air when the air magnitude lowered drastically.

The simulations that were conducted in ANSYS Fluent had the same input parameters that allowed the comparison of the results below. In order to compare and contrast the results, the simulation results have the same scale of the air velocity as the PIV measurements ranging from 0 to $17 \mathrm{~m} / \mathrm{s}$. The results are shown in Figs. 4 and 5 .

\subsection{Measurement distance from the air terminal device: $6 \mathrm{~m}$}

The next step was to observe how the air throw changed at $6 \mathrm{~m}$ from the air terminal device. The measurements were carried out for the same airflows as in the previous paragraph to compare and contrast the advantages and disadvantages of the changing geometry of the air terminal device. The comparison also took under consideration how the minimum flow would behave without the change in diameter of the air terminal device. In order to compare and contrast the results, the simulation had the same scale of air velocity as the PIV measurements, ranging from 0.4 to $1.9 \mathrm{~m} / \mathrm{s}$. The results are shown in Figs. 6,7 and 8 .

Figures 6,7 and 8 show the change in the air velocity depending on the flow magnitude as well as the geometry of the air terminal device. In Fig. 6 , the results for the high airflow and ATD setting 1 are shown in the distance of $6 \mathrm{~m}$ from the air supply. The air velocity is measured to be an average of $1.9 \mathrm{~m} / \mathrm{s}$. When lowering the air magnitude through the system and without changing the diameter, the air velocity lowers to $0.5-0.7 \mathrm{~m} / \mathrm{s}$ (Fig. 7), meaning that it has reached its maximum air throw. When comparing these two cases, it can be noticed that in the case where the air magnitude is set as maximum, the air continues to flow further into the ventilated zone thanks to its high velocity, whereas in the second case the air has decelerated to a minimum and does not flow any further. This means that in the second case, the occupants inside such a room seated further away from the air supply would have lower air quality. When the geometry of the air terminal device is altered as shown in Fig. 8 (ATD setting 2), the 


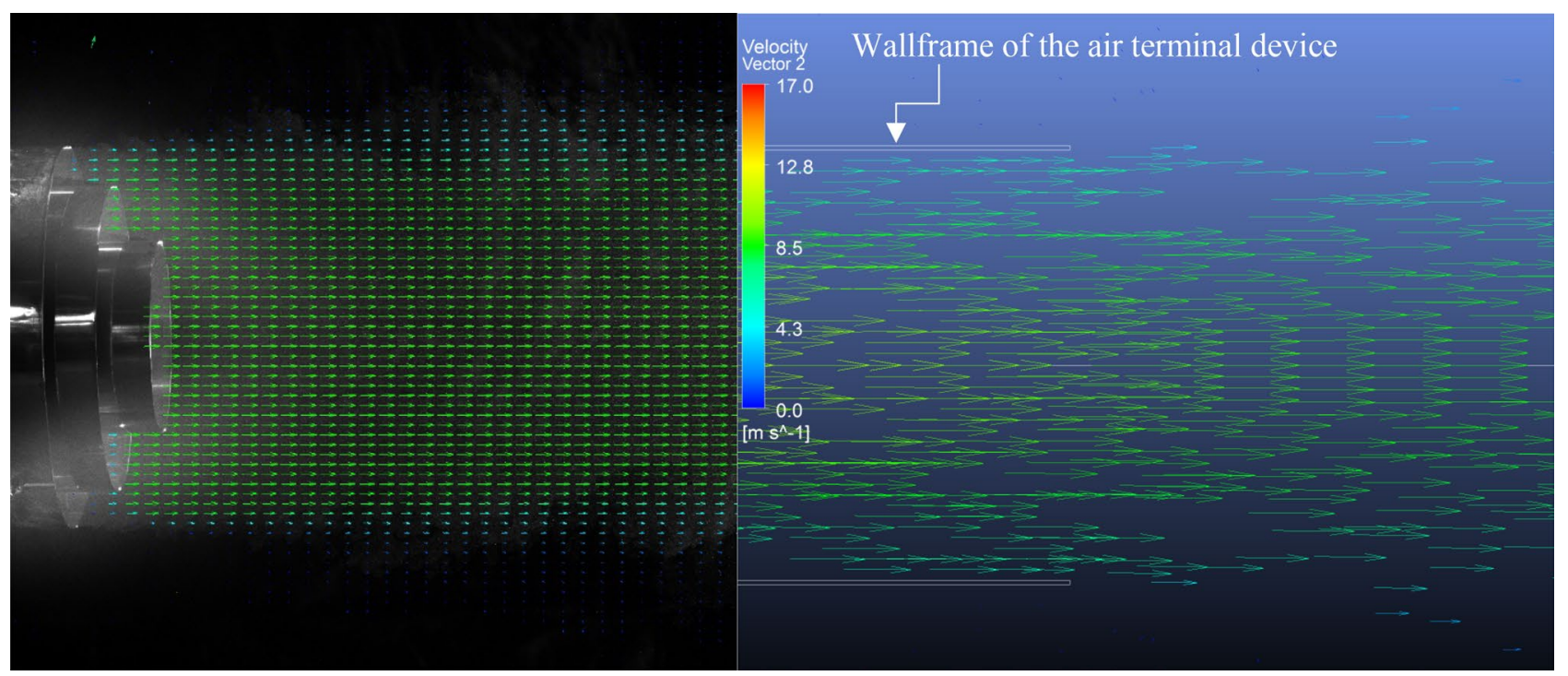

Fig. 4 Results for the flow magnitude of $750 \mathrm{~m}^{3} / \mathrm{h}$ and ATD setting 1, distance from the air terminal device 0 m; left: PIV measurement; right: ANSYS Fluent results

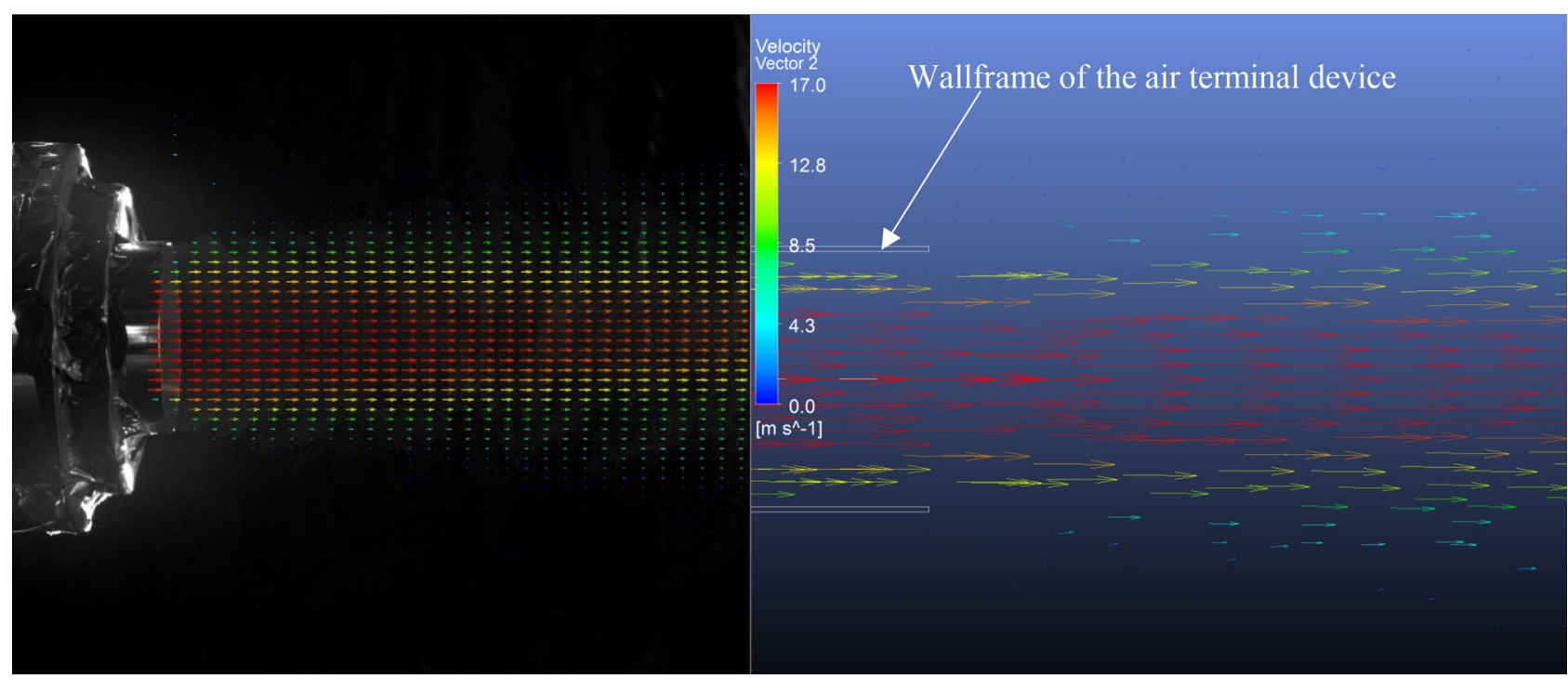

Fig. 5 Results for the flow magnitude of $360 \mathrm{~m}^{3} / \mathrm{h}$ and ATD setting 2, distance from the air terminal device 0 m; left: PIV measurement; right: ANSYS Fluent results

air velocity at the distance of $6 \mathrm{~m}$ from the air source is $1.6 \mathrm{~m} / \mathrm{s}$, meaning that the air does continue to flow further and the ATD provides fresh, clean air for the occupants.

To compare and contrast how the velocity differed in both cases, a series of histograms showing the percentage of velocity vectors were made. Figures 9 and 10 show histograms of the velocity vectors $6 \mathrm{~m}$ from the air terminal device. The first presents the case with the maximum airflow and ATD setting 1. The value of the vectors is spread out more evenly, and the value of the majority ranges from 1.55 to $1.77 \mathrm{~m} / \mathrm{s}$. In the second case, where the minimum airflow and ATD setting 2 were employed, the value of the majority of vectors is between 1.45 and $1.55 \mathrm{~m} / \mathrm{s}$. Despite not being ideal, this comparison proves that the alteration of the diameter can contribute to maintaining the air throw as the average miscalculation is equal to an average of $0.2 \mathrm{~m} / \mathrm{s}$ according to the histograms. 


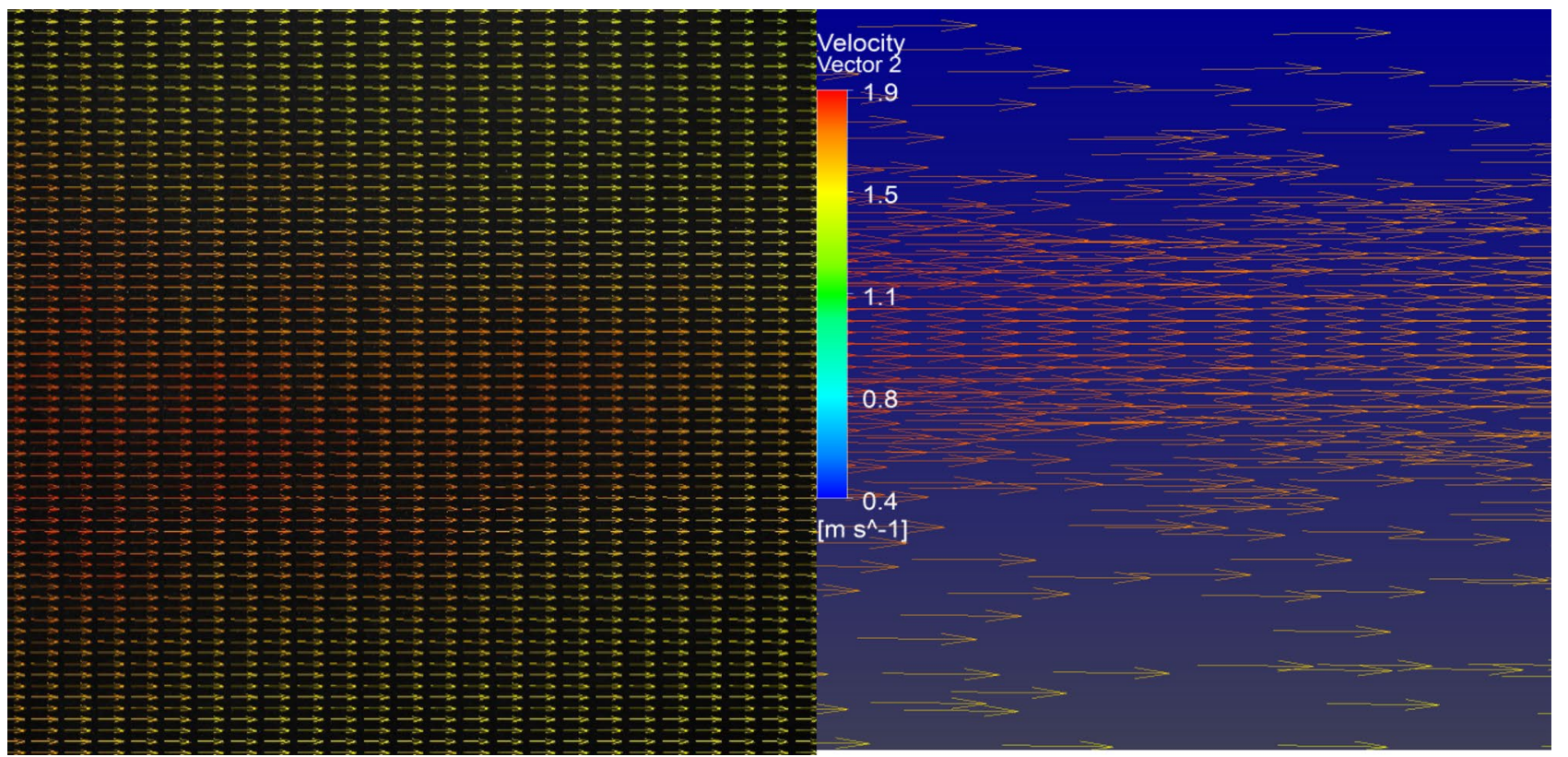

Fig. 6 Results for the flow magnitude of $750 \mathrm{~m}^{3} / \mathrm{h}$ and ATD setting 1, distance from the terminal device 6 m; left: PIV measurement; right: ANSYS Fluent results

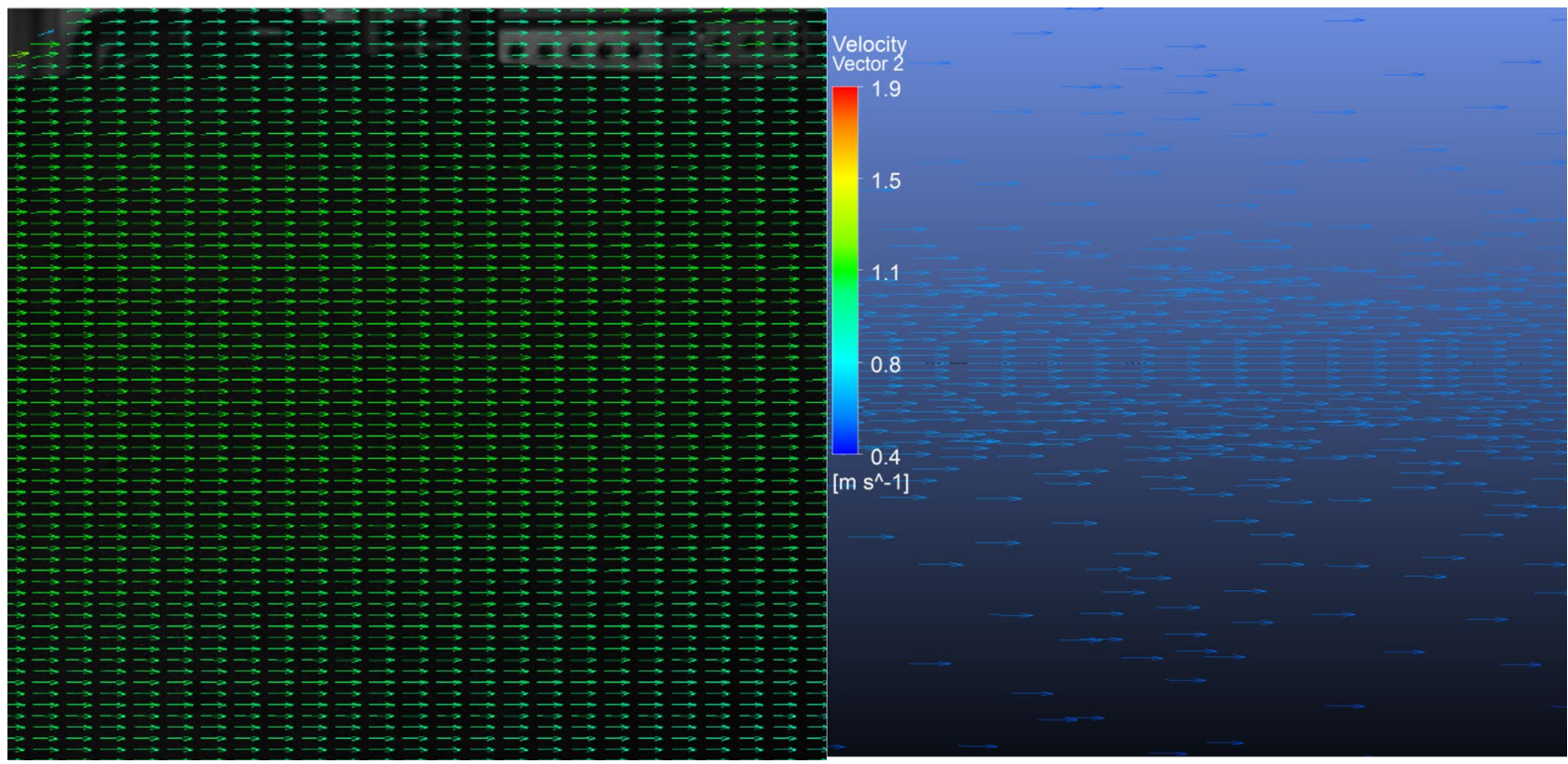

Fig. 7 Results for the flow magnitude of $360 \mathrm{~m}^{3} / \mathrm{h}$ and ATD setting 1, distance from the air terminal device $6 \mathrm{~m}$; left: PIV measurement; right: ANSYS Fluent results

\section{Discussion of the results}

As the results from the study show, when using constant diameter of the air terminal device, the air throw lowers with the changes in the VAV system. When lowering the air magnitude through the system and without changing the geometry of the air terminal dive, the air throw has a maximum of $6 \mathrm{~m}$ as its velocity falls to $0.5-0.6 \mathrm{~m} / \mathrm{s}$ (Fig. 7). However, when using the proposed air terminal device with a dynamically changing geometry to accelerate the air when it enters the ventilated zone, the velocity at the given check point was stable, meaning that the air throw would also be stable as shown in Figs. 8,

\section{SN Applied Sciences}




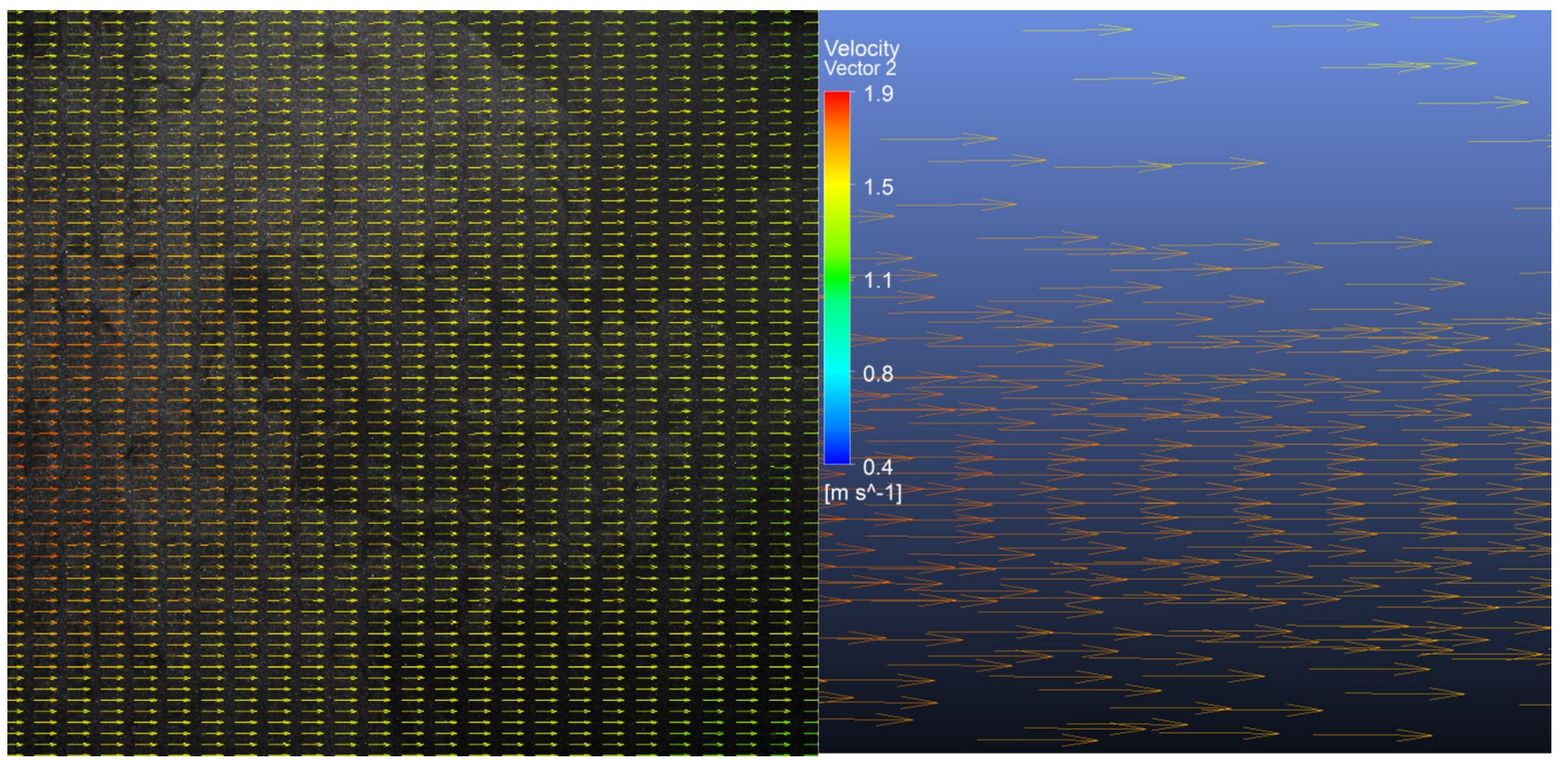

Fig. 8 Results for the flow magnitude of $360 \mathrm{~m}^{3} / \mathrm{h}$ and ATD setting 2, distance from the air terminal device $6 \mathrm{~m}$; left: PIV measurement; right: ANSYS Fluent results

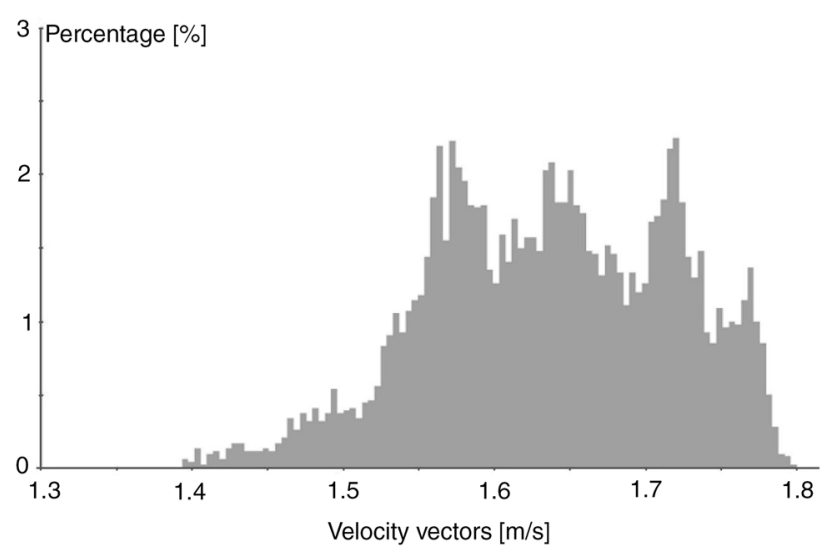

Fig. 9 Velocity histogram for the maximum airflow and ATD setting

9 and 10 . This means that the indoor air quality can be improved by using such systems as the air throw does not depend on the airflow through the system. In their review, Okochi and Yao [26] described the developments and advancement of VAV systems. They stated that one of the main problems with VAV systems is the balancing and distribution of the airflow. This study proves that thanks to the dynamically changing geometry of the ATD, it is possible to improve the air distribution. Similar findings were discovered by Hurnik [27], who used a specialized mixing chamber to maintain the constant airflow magnitude through a ADT and in consequence the air throw. The research concluded that it is possible to

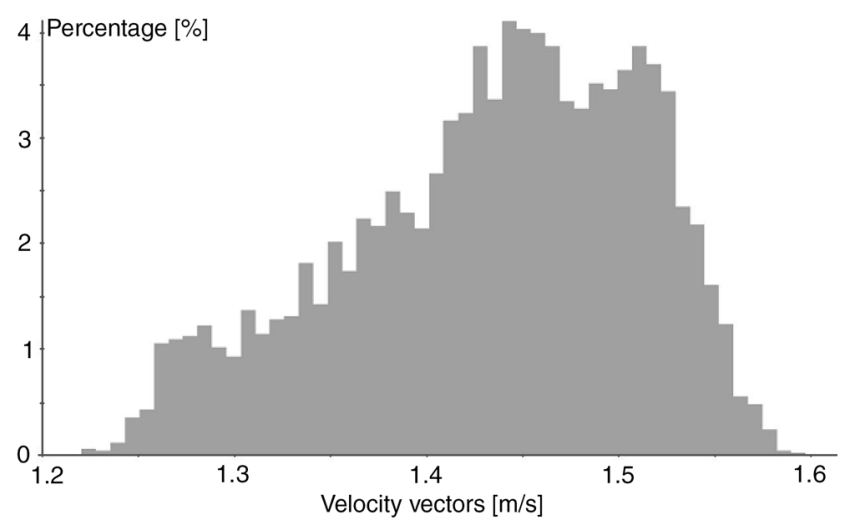

Fig. 10 Velocity histogram for the minimum airflow and ATD setting 2

maintain a steady air throw when using VAV ventilation systems. The PIV measurements allowed a detailed view of the flow vectors. Thanks to its noninvasive characteristics, it was possible to measure the air velocity without disrupting the flow with measurement equipment giving a true reflection of the flow pattern.

\section{Conclusion}

The improvement in indoor air quality (IAQ) is an ongoing subject that is fundamental to human comfort and health. The lack of a properly equipped and measured ventilation system in airtight structures may have harmful effects on 
occupants. This is why the aim of this research was to study the possibility of improvement of a VAV ventilation system.

When using classic VAV systems, the same air terminal device is used despite the changing airflow through the system. As the results from the study show, when using the same geometry of the air terminal device designed for the maximum airflow in VAV systems, the velocity of the air lowers when the airflow magnitude lowers through the system according to its characteristics. This indicates that the air throw of classic VAV systems is strictly defined by the airflow.

However, when using the proposed air terminal device with a dynamically changing geometry, the air throw remains roughly the same when altering the diameter accordingly to the airflow. This means that the indoor air quality can be improved by using such systems, since the air throw does not depend on the airflow through the ventilation system and can be adjusted according to the air magnitude. The system using this solution would maintain proper IAQ and help maintain the hygienic levels of contaminants.

Both the PIV measurements and CFD simulations are shown as valid tools for the indication of IAQ. The limitation of the study was that the PIV system was a two-dimensional one. However, the results indicate that the velocity field was shown sufficiently detailed for the purposes of this study. This motivates further studies on airflow patterns for other outlet air terminal devices and further defines their influence on thermal and hygienic comfort.

Acknowledgements This study was funded by The Cracow University of Technology (Grant No. E3/586/2018/DS).

\section{Compliance with ethical standards}

Conflict of interest On behalf of all authors, the corresponding author states that there is no conflict of interest.

Open Access This article is distributed under the terms of the Creative Commons Attribution 4.0 International License (http://creativeco mmons.org/licenses/by/4.0/), which permits unrestricted use, distribution, and reproduction in any medium, provided you give appropriate credit to the original author(s) and the source, provide a link to the Creative Commons license, and indicate if changes were made.

\section{References}

1. Awbi HB (2017) Sustainable solutions for energy and environment. Energy Procedia 112:277-286. https://doi.org/10.1016/j. egypro.2017.03.1098

2. Nehr S, Hösen E, Tanabe S (2017) Emerging developments in the standardized chemical characterization of indoor air quality. Environ Int 98:233-237. https://doi.org/10.1016/j.envin t.2016.09.020

\section{SN Applied Sciences}

3. Pantazaras A, Lee SE, Santamouris M, Yang J (2016) Predicting the $\mathrm{CO}_{2}$ levels in buildings using deterministic and identified models. Energy Build 127:774-785. https://doi.org/10.1016/J. ENBUILD.2016.06.029

4. Vringer K, van Middelkoop M, Hoogervorst N (2016) Saving energy is not easy: an impact assessment of Dutch policy to reduce the energy requirements of buildings. Energy Pol 93:2332. https://doi.org/10.1016/j.enpol.2016.02.047

5. Strom-Tejsen P, Zukowska D, Wargocki P, Wyon DP, Strøm-Tejsen P, Zukowska D, Wargocki P, Wyon DP, Strom-Tejsen P, Zukowska D, Wargocki P, Wyon DP (2015) The effects of bedroom air quality on sleep and next-day performance. Indoor Air. https://doi. org/10.1111/ina.12254

6. Wargocki P, Wyon DP (2013) Providing better thermal and air quality conditions in school classrooms would be cost-effective. Build Environ 59:581-589. https://doi.org/10.1016/j.build env.2012.10.007

7. Langer S, Bekö G, Bloom E, Widheden A, Ekberg L (2015) Indoor air quality in passive and conventional new houses in Sweden. Build Environ 93:92-100. https://doi.org/10.1016/j.build env.2015.02.004

8. Ng LC, Persily AK, Emmerich SJ (2015) IAQ and energy impacts of ventilation strategies and building envelope airtightness in a big box retail building. Build Environ 92:627-634. https://doi. org/10.1016/j.buildenv.2015.05.038

9. Meslem A, Bode F, Croitoru C, Nastase I (2014) Comparison of turbulence models in simulating jet flow from a crossshaped orifice. Eur J Mech B/Fluids 44:100-120. https://doi. org/10.1016/j.euromechflu.2013.11.006

10. Pu L, Li Y, Xiao F, Ma Z, Qi D, Shen S (2014) Effects of different inlet vent positions on the uniformity of humidity inside a building chamber. Energy Build 76:565-571. https://doi.org/10.1016/j. enbuild.2014.03.022

11. PN-EN 12238:2002 Wentylacja budynków - Elementy końcowe Badania aerodynamiczne i wzorcowanie w zakresie zastosowań strumieniowego przepływu powietrza

12. Szczepanik-Ścisło N, Schnotale J (2017) Modelowanie CFD nawiewnika $z$ dynamicznie zmieniającą się geometrią $w$ celu poprawy efektywności wentylacji w systemach VAV. Ciepłownictwo, Ogrzewnictwo, Wentylacja 1:38-42. https:// doi.org/10.15199/9.2017.4.7

13. Li A, Yang C, Ren T, Bao X, Qin E, Gao R (2017) PIV experiment and evaluation of air flow performance of swirl diffuser mounted on the floor. Energy Build 156:58-69. https://doi.org/10.1016/j. enbuild.2017.09.045

14. Hu G, Tse KT, Chen ZS, Kwok KCS (2017) Particle Image Velocimetry measurement of flow around an inclined square cylinder. J Wind Eng Ind Aerodyn 168:134-140. https://doi.org/10.1016/J. JWEIA.2017.06.001

15. Tang C, Li E, Li H (2018) Particle image velocimetry based on wavelength division multiplexing. Opt Laser Technol 98:318325. https://doi.org/10.1016/J.OPTLASTEC.2017.08.013

16. ANSYS (2011) ANSYS FLUENT Theory Guide. Inc. Release 14.0, (http://www.ansys.com). Accessed Nov 2018

17. Ning $M$, Mengjie S, Mingyin C, Dongmei P, Shiming D (2016) Computational fluid dynamics (CFD) modelling of air flow field, mean age of air and $\mathrm{CO}_{2}$ distributions inside a bedroom with different heights of conditioned air supply outlet. Appl Energy 164:906-915. https://doi.org/10.1016/j.apenergy.2015.10.096

18. Pang L, Li P, Bai L, Liu D, Zhou Y, Yao J (2018) Optimization of air distribution mode coupled interior design for civil aircraft cabin. Build Environ 134:131-145. https://doi.org/10.1016/j. buildenv.2018.02.019

19. Popovici CGCG (2017) HVAC system functionality simulation using ANSYS-Fluent. In: Energy Procedia. Elsevier, Amsterdam, pp 360-365 
20. Elmaghraby HA, Khalil EE (2015) Thermal comfort through mixing and personalized ventilation systems. In: 13th international energy conversion engineering conference. https://doi. org/10.2514/6.2015-3821

21. Einberg G, Hagström K, Mustakallio P, Koskela H, Holmberg $S$ (2005) CFD modelling of an industrial air diffuser: predicting velocity and temperature in the near zone. Build Environ 40:601-615. https://doi.org/10.1016/j.buildenv.2004.08.020

22. Matveev SGS, Zubrilin IA, Orlov MY, Matveev SGS (2015) Numerical investigation of the influence of flow parameters nonuniformity at the diffuser inlet on characteristics of the GTE annular combustion chamber. Volume 4A: Combustion, fuels and emissions V04AT04A051. https://doi.org/10.1115/gt2015-42676

23. Nada SA, El-Batsh HM, Elattar HF, Ali NM (2016) CFD investigation of airflow pattern, temperature distribution and thermal comfort of UFAD system for theater buildings applications. J Build Eng 6:274-300. https://doi.org/10.1016/j.jobe.2016.04.008

24. Nadarajan M, Kirubakaran V (2017) Simulation studies on small rural residential houses using sustainable building materials for thermal comfort-case comparison. Adv Build Energy Res 11:193-207. https://doi.org/10.1080/17512549.2016.1215260

25. Khatoon S, Kim M-H (2017) Human thermal comfort and heat removal efficiency for ventilation variants in passenger cars. Energies 10:1710. https://doi.org/10.3390/en10111710

26. Okochi GS, Yao Y (2016) A review of recent developments and technological advancements of variable-air-volume (VAV) airconditioning systems. Renew Sustain Energy Rev 59:784-817. https://doi.org/10.1016/j.rser.2015.12.328

27. Hurnik M (2018) Systemy klimatyzacji o zmiennej ilości powietrza z indukcujnymi regulatorami przepływu. Wydawnictwo Politechniki Śląskiej, Gliwice

Publisher's Note Springer Nature remains neutral with regard to jurisdictional claims in published maps and institutional affiliations. 